Running Head: N Limitations and Tree Growth in a Ponderosa Pine Forest

\title{
NITROGEN CAN LIMIT OVERSTORY TREE GROWTH FOLLOWING EXTREME STAND DENSITY INCREASE IN A PONDEROSA PINE FOREST
}

\author{
L.A. MARSHALL ${ }^{\mathrm{a}, \mathrm{b} *}$, DONALD A. FALK ${ }^{\mathrm{a}, \mathrm{b}}$, NATE G. MCDOWELL ${ }^{\mathrm{c}}$ \\ ${ }^{a}$ School of Natural Resources and the Environment, The University of Arizona, Tucson, AZ 85721-0045, USA \\ ${ }^{b}$ Laboratory of Tree-ring Research, The University of Arizona, Tucson, AZ 85721-0045, USA \\ 'Pacific Northwest National Laboratory, Richland, WA 99352, USA
}

\begin{abstract}
Extreme stand density increases have occurred in ponderosa pine forests throughout the western U.S. since the early $20^{\text {th }}$ Century, with adverse implications for growth, physiological functioning, and mortality risk. Identifying primary stressors on large, old overstory trees in dense forests can inform management decisions to promote resilience and survival. We tested the impact of stand density increase on overstory treering growth, and the relative influence of water and nitrogen, in an old-growth ponderosa pine forest subject to variable density increase. We measured annual tree-ring growth and carbon discrimination in trees before stand density increased, in a climatically-similar period post-density increase, and in recent transition to drought. We expected density-driven water stress to drive reduced tree-ring growth in overstory trees in dense stands. We found reduced growth and higher mortality in dense stands, but nitrogen rather than water constrained growth, as determined by carbon isotope discrimination in tree rings, leaf nitrogen concentration, and soil nitrogen supply. In dense stands, less available nitrogen limited photosynthetic rate, leading to reduced assimilation of intracellular ${ }^{13} \mathrm{C}$ and higher discrimination with low tree-ring growth and a reduced relationship with climate. This unexpected result illustrates that a variety of limiting factors can influence forest dynamics, as density-driven nitrogen limitation interacts with water stress to influence tree growth and physiological functioning.
\end{abstract}

Keywords: dendroecology; tree-ring width; limiting factors; stable carbon isotopes; stand density; water stress; soil nitrogen; soil types; growth limitation.

\section{INTRODUCTION}

Fire exclusion followed by an increase in forest stand density is a common natural history progression for many areas of the contemporary western United States, with serious implications for forest management and the perpetuation of ecologically valuable large, old trees (Kolb et al. 2007; Hurteau et al. 2014). Before fire exclusion, ponderosa pine (Pinus ponderosa Douglas ex C. Lawson) forests burned frequently. Low-severity fires removed smaller trees, resulting in low stand densities with spatial variation in forest structure (Allen et al. 2002; Moore et al. 2004). Recruitment in ponderosa pine forests is episodic, concentrated in wetter periods with lower fire frequency (Brown and $\mathrm{Wu}$ 2005; Meunier et al. 2014). Fire exclusion led to higher tree density as recruitment occurred without thinning by frequent fire. Greater tree density in turn increased fuel load and the risk of high-severity fire (Fulé et al. 1997; Moore et al. 2004). Large, old trees are particularly affected by increased density in multiple ways. Competitive interactions, a greater risk of extreme fire behavior and bark beetle attack, and drought effects interact with other factors to increase the chance of overstory tree mortality (Kolb et al. 2007; Allen et al. 2010; van Mantgem et al. 2018).

Higher stand density results from conditions favoring recruitment and survivorship over time. Soil characteristics including soil depth, water availability, and parent material can increase water and nutrient availability to seedlings, such that higher survivorship and establishment occurs in certain areas (Abella et al. 2014). Stand density drives competition-mediated changes to water and nutrient availability, so greater stand density can indicate a greater number of trees sharing a limited resource pool. Trees in dense stands tend to have reduced growth, lower leaf area, and may show physiological impacts including reduced gas exchange (McDowell et al. 2003; Sala et al. 2005).

Competition-driven water stress leads to stomatal closure, limits carbon acquisition and constrains tree growth. A reduced ability to photosynthesize puts a tree at risk of death through carbon starvation and/or hydraulic failure in 
the event of prolonged drought stress (McDowell 2011). Competition is a contributing factor to tree mortality in dense stands, but is difficult to disentangle from other factors such as direct drought effects and vulnerability to insect attack (Allen et al. 2010; Das et al. 2011).

Stable-carbon isotope discrimination $\left(\Delta^{13} \mathrm{C}\right)$ in trees reflects water limitation in arid and semiarid ecosystems. Discrimination is correlated negatively with water stress, as fractionation of lighter and heavier isotopes is influenced by the rate of stomatal conductance (McCarroll and Loader 2004). Tree-ring cellulose discrimination is a reliable measure of relative water stress over time, because it tracks the influence of environmental variation on treewater relations utilizing temporally-stable components of wood, such as cellulose and hemicellulose (McCarroll and Loader 2004). However, nitrogen availability can complicate the use of discrimination as a measure of water stress.

Nitrogen is an important factor in $\mathrm{C}_{3}$ plant carbon assimilation. It makes up a substantial portion of proteins found in leaves, notably the Rubisco enzyme (ribulose-1,5- bisphosphate carboxylase/oxygenase), which catalyzes carboxylation during photosynthesis. When there is higher leaf nitrogen per unit area, more nitrogen goes to proteins active in the Calvin cycle, and $\mathrm{CO}_{2}$ assimilation is higher (Evans 1989). Net photosynthesis is correlated positively with leaf nitrogen concentration, and thus with greater growth and tree-ring widths (Lupi et al. 2013). Stand density can also influence nitrogen cycling. High stand density leads to reduced belowground resource uptake per individual, constraining nitrogen acquisition and thus photosynthetic rate. This can lead to a disjunction between discrimination and water stress by trees in dense stands (De Boeck et al. 2006; Rennenberg et al. 2009).

Here we consider the impacts of density-driven resource limitation on overstory ponderosa pine, as a legacy of fire exclusion. We examined the physiological responses to stand density-mediated water and nitrogen availability, leading to growth and mortality changes in overstory trees in a relatively intact natural landscape. Our null hypothesis $\left(\mathrm{H}_{0}\right)$ was that overstory trees in dense stands would show reduced tree-ring growth and reduced carbon isotope discrimination, when compared to trees in open stands. Here the primary mechanism would be competitiondriven water stress. Our alternate hypothesis $\left(\mathrm{H}_{1}\right)$ was that decreased availability of nitrogen in dense stands would constrain photosynthetic rates, leading to reduced growth in dense stands while discrimination rates remained equal or greater than that of overstory trees in open stands. In this condition, water stress would be secondary to nitrogen limitation reducing trees' capacity to assimilate carbon. Understanding the effects of high stand density on these forests facilitates a deeper knowledge of how increased stand density affects the physiological functioning of overstory ponderosa pine.

\section{MATERIALS AND METHODS}

The study area is the 256-ha Monument Canyon Research Natural Area (MCRNA), located in the Jemez Mountains ( $35.805556^{\circ} \mathrm{N},-106.627222^{\circ} \mathrm{W}$; mean elevation $2469 \mathrm{~m}$ a.s.l.), in northern New Mexico, USA (Figure 1). MCRNA was established in 1932 and protected from logging, although not from fire exclusion (Allen 1998). MCRNA is predominantly old-growth ponderosa pine forest, covering portions of San Juan and Cat Mesa. Substrates are of volcanic origin, primarily Lower Bandelier tuff (Otowi member) (QBO) and El Cajete pumice (QEC), with Holocene alluvium in drainages (Kelley et al. 2003; Goff et al. 2005). High tree density closely aligns with QEC substrate origin on San Juan and portions of Cat Mesa (Figure 1). Mesa-level differences were controlled by analyzing trees in open and dense stands across mesas. Frequent low-severity surface fire was common from the 1500s to the late 1800s (Falk et al. 2007; Swetnam et al. 2016). Fire exclusion around 1900 was followed by a massive increase in stand density across parts of MCRNA during the first half of the $20^{\text {th }}$ Century.

\section{Climate and Periods of Study}

We identified three periods for analysis: (1) prior to stand densification (1897-1907, hereafter "Pre"), (2) postdensification with similar climate (1971-1980, hereafter "Post"), and (3) the shift to sustained regional drought (1990-2007, hereafter "Recent"). We used 1875-2007 to review longer-term growth changes relative to climate.

For climate response we used PRISM reconstructions and Palmer Drought Severity Index (PDSI). Selected climate variable means and standard deviation are summarized by period in Table 1. Growing-season PDSI (March-September) was calculated from the closest gridpoint, 119 (Cook et al. 2008). In southwestern North America, PDSI is correlated strongly with previous winter precipitation, and generally well correlated with tree-ring width (St. George et al. 2010). Growing season (March-September) mean temperature $\left({ }^{\circ} \mathrm{C}\right)$ and VPD $(\mathrm{hPa})$ and water-year precipitation ( $\mathrm{mm}$, previous October-current September) were calculated using monthly PRISM values from the 4-km cell encompassing MCRNA at $35.8040^{\circ} \mathrm{N},-106.6192^{\circ} \mathrm{W}$ (PRISM Climate Group 2018). Climate variables were correlated with mean annual tree response variables for each time period and density class using Pearson's $r$, and significance tested using two-tailed t-tests. 


\section{Sampling and Variables}

We used three response variables: tree-ring carbon isotope discrimination $\left(\Delta^{13} \mathrm{C}\right)$, foliar and soil nitrogen (leaf $\%$, soil net supply $\left.\mu \mathrm{g} / 10 \mathrm{~cm}^{2}\right)$, and basal area increment $(\mathrm{BAI} \mathrm{cm})^{2}$. We selected dominant overstory ponderosa pine trees in currently dense and open natural communities across MCRNA with similar substrate conditions, but differing tree densities. Data analysis was performed and figures produced using R tidyverse and ggthemes packages (Arnold 2018; R Core Team 2016; Wickham 2017). We used the fire history package FHAES for fire interval analysis (Brewer et al. 2016).

We considered a site dense if it fell above the median density across all sites ( 2300 stems ha $\left.^{-1}\right)$, and open if

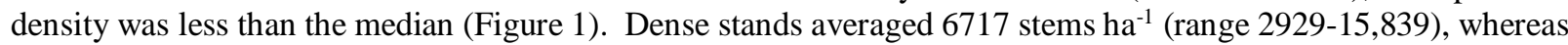
open stands averaged 776 stems ha $^{-1}$ (range 186-2128) across all size classes. Open stands were dominated by clusters of 2-5 large overstory trees with herbaceous understory. Dense stands were characterized by numerous small diameter $(<15 \mathrm{~cm} \mathrm{DBH})$ ponderosa pine stems with interlocking canopies and low light reaching the forest floor. Understory plants were scarce or absent, with deep needle litter. The density increase at MCRNA dates primarily to a recruitment pulse in the early $20^{\text {th }}$ Century combined with decades of fire exclusion that reduced small tree mortality (Allen 1998; Falk 2004). Over the period 1600-1900 at MCRNA, a fire exceedance interval longer than 11.98 years had a $p<<0.001$ (minimum 2 scarred trees and 5 recorders active), yet by 1971, 70 years had passed without fire, and forest structure had undergone extensive changes.

We used a gridded plot design to compare stand density with fire history and geologic features across MCRNA (Figure 1), with twenty-eight 0.01 ha square plots adjacent to a gridpoint, where all trees $\geq 2.5 \mathrm{~cm} \mathrm{DBH}$ were counted and measured, and nearby fire scar samples were collected by Falk (2004). We calculated mean stand density and standard error $\left(\mathrm{stems} \mathrm{ha}^{-1}\right)$ and tested for significance between variables using two sample t-tests assuming unequal variance, by mesa landform and geologic unit (El Cajete Pumice versus others) (Kelley et al. 2003; Goff et al. 2005).

Thirty living overstory trees, "target trees", all $\geq 40$-cm diameter at breast height (DBH, $1.4 \mathrm{~m}$ ) and mature by 1900 , were selected randomly from the set of gridded plots (15 trees per dense/open condition). For leaf nitrogen, additional understory ponderosa pines were selected randomly for sampling within the same stands. We prepared and crossdated tree cores using standard dendrochronological techniques (Speer 2010). Cores were initially collected in 2004. Additional cores were collected in 2008 to capture the recent drought period, and to minimize potential confounding effects of substrate on density by sampling in dense and open areas across each mesa in MCRNA. Trees were cored with 12-mm borers at $c a .140 \mathrm{~cm}$ for carbon isotope analysis and $c a .10 \mathrm{~cm}$ above the root crown with 5-mm borers for ring-width analyses. All cores were dried, 5-mm cores were mounted to plywood with glue, and then sanded and crossdated to annual resolution. The 12-mm cores for isotopic analysis were surfaced with a razor to provide a dateable surface and not mounted to avoid contamination.

\section{Stem Growth, Mortality, Water and Nitrogen}

We measured annual tree-ring growth increment from target tree cores using a Velmex measuring system (Velmex, Inc, Bloomfield, NY, USA) to a precision of $0.001 \mathrm{~mm}$. To correct for age-growth trends while retaining interdecadal variation, we used basal area increment $\left(\mathrm{BAI}, \mathrm{cm}^{3}\right)$, calculated from measured tree-ring widths assuming a circular tree bole, for the length of each series (Biondi and Qeadan 2008). Mean annual BAI chronologies and cumulative mean basal area (BA) were calculated for the period 1875-2007 for dense and open stands. We tested for significant differences using a two tailed t-test assuming unequal variance in mean annual BAI between and within stands and time periods.

We calculated mortality in target trees using counts of live and dead trees within 0.1 ha plots around a subset of gridpoints, over the period 2000-2006. We compared the proportion of dead trees in 2006 to 2000 in dense and open stands, and tested for significance using a two tailed t-test.

We used carbon isotope discrimination $\left(\Delta,{ }^{13} \mathrm{C} /{ }^{12} \mathrm{C} \%\right)$ in tree-ring cellulose to test the physiological impacts of increased stand density. After cores for isotopic analysis were dated, the complete annual rings (earlywood and latewood) for each of the three analysis periods were separated and milled individually. Each sample was processed into $\alpha$-cellulose using chemical treatment to remove extractives and lignin (McCarroll and Loader 2004). Cellulose was isolated in order to minimize the potential for mobile carbon to influence results, as the earlier analysis periods in some cores crossed the sapwood-heartwood boundary (McCarroll and Loader 2004; Leavitt 2010).

Cellulose was analyzed in a Micromass IsoPrime continuous-flow isotope ratio mass spectrometer to measure annual $\delta^{13} \mathrm{C}$ (McCarroll and Loader 2004). Discrimination values for each tree-year were calculated with 
adjustments for the atmospheric trend in $\delta^{13} \mathrm{C}$ using ice core atmospheric records (Keeling et al. 2005). Mean $\Delta$ and standard error were calculated for each year sampled, for dense and open stands. We used squared Pearson's correlation coefficients $\left(r^{2}\right)$ to determine the degree to which reconstructed climate variables explained variation in $\Delta$, and $\Delta$ explained BAI, by stand density and sampling period. Two sample t-tests for significance were conducted between stand densities and across sampling periods.

We collected soil nitrogen data over a 9-week period during June-August 2008. We used Plant Root Simulator (PRS) probes (Western Ag, Saskatoon, Canada) set in dense and open stands to find soil nitrogen net supply (total available nitrogen, $\mathrm{NH}_{4}$, and $\mathrm{NO}_{3}, \mu \mathrm{g} / 10 \mathrm{~cm}^{2}$ ) for a 9-week burial period. Probes were placed at a 10 $\mathrm{cm}$ depth among roots, at cardinal points around the focal overstory trees within the radius of the tree crown. Some dense stands in MCRNA were thinned during the winter of 2006-7 as part of an ongoing restoration project, so additional dense stands ( $<150 \mathrm{~m}$ from boundary of MCRNA) were sampled outside the thinning treatment area for soil $\mathrm{N}$ comparison, along with remaining dense stands within MCRNA (Figure 1). We calculated the mean and standard error in $\mathrm{N}$ for soils in dense and open stand conditions, and tested for significant differences using a two sample t-test assuming equal variance.

We sampled foliage in winter 2006 from the sunlit canopy of 11 overstory and 7-10 understory trees in dense and open stands. Foliage was harvested using a shotgun from high on the south side of the crown to maximize leaf sun exposure and minimize the potential confounding effect of shading (Bond et al. 1999). Leaf samples were dried and homogenized by tree before analysis of nitrogen (\%), carbon (\%), and C:N ratio per leaf weight in grams, using a dry mass analyzer at Los Alamos National Laboratory. We found the mean and standard error of $\% \mathrm{~N}$ in overstory and understory tree leaves in dense and open stand conditions and tested for significant differences using a twosample t-test assuming equal variance.

\section{Stand Density, Soils, and Fire}

Fire-scar dating indicates the cessation of widespread fire in MCRNA by 1900, with no subsequent fire scarring more than $10 \%$ of samples (Falk 2004). We tested for significant differences in mean fire interval and years since fire for events from 1801-1981, by density (dense versus open), soils, and mesas using two tailed t-test assuming unequal variance. We found mean years since fire (YSF) intervals in 50-year segments covering $c a$. one century before and after fire exclusion: 1800-1849, 1850-1899, 1900-1949, and 1950-1981. We tested for significance between these periods using a single-factor ANOVA.

Inter-tree competition was quantified as an index of competitor basal area within an allometrically-determined radius around each overstory tree. Within a search radius of $40 \times \mathrm{DBH}(\mathrm{m})$, we measured distance to the target overstory tree, and DBH of each competitor tree taller than $1.4 \mathrm{~m}$. Basal area of competitors was summed for trees in dense and open stands by distance. We used the distance-weighted competition equation sum ((diameter competitor $\mathrm{cm} /$ diameter target $\mathrm{cm}$ )/distance $\mathrm{cm}$ ) as an index of competition in dense and open stands (Lorimer 1983; Burkhart and Tomé 2012). From this we calculated competitor tree density surrounding target trees (stems ha ${ }^{-1}$ ). In one case of extreme density and limited resources, we surveyed $2 / 3$ of the surrounding area (1585 competitor stems), and extrapolated to the full area.

\section{RESULTS}

\section{Stem Growth, Mortality, Water and Nitrogen}

Mean BAI $\left(\mathrm{cm}^{2}\right)$ was significantly different between dense and open stands in the Post $(p=0.003)$ and Recent $(p<0.001)$ period, whereas mean discrimination $(\Delta \%)$ between dense and open stands was significant only in the Post period $(p<0.001)$ (Table 1). Lower growth yet higher discrimination in dense stands means $\mathrm{H}_{0}$ is rejected in the Post period. In the Recent period discrimination was not different between stands, but BAI in dense stands was much lower, suggesting a disconnect between radial growth and discrimination (Table 1).

From 1875-2007 growth was lower in open stands than dense stands in only four years $(1891,1918,1946$, and 2004) (Figure 2c). The mean annual BAI of target trees (mean $\pm \mathrm{se}^{2}$ ) for $1875-2007$ was $6.84 \pm 0.29$ in dense stands, and $10.68 \pm 0.37$ in open stands $(p<0.001)$. Cumulative basal area increment $\left(\mathrm{cm}^{2}\right)$ diverged between stands over time, with dense stands accumulating less wood, at a slower rate (Figure 2d). As stand density increased, the rebound in mean ring growth following a severe event (such as drought in 1956 or 1996) became reduced in dense stands, suggesting a longer time to recover from stress. Tree mortality tended to be higher in dense stands from 2000-2006, although because of high variance the difference was not statistically significant. In dense 
stands, the mean proportion of dead trees increased by $5.7 \%$, whereas in open stands, dead trees increased by $0.9 \%$ over this time period. At the densest site sampled, $88 \%$ of trees $>25 \mathrm{~cm}$ DBH were recorded dead in 2006.

Discrimination $(\Delta \%)$ was similar between dense and open stands in the Pre period, significantly different and higher in dense stands in the Post period, and similarly high in the Recent period (Figure 2a). During the Pre period, the similarity in $\Delta$ and BAI between dense and open stands suggests similar access to water and resources, and similar effects of top-down controlling mechanisms, such as fire, across MCRNA. Over time, we observed an increasing trend in $\Delta$ for all stands, even after correcting for drift in atmospheric $\delta^{13} \mathrm{C}$ (Figure $2 \mathrm{~b}$ ).

Reconstructed summer PDSI predicted BAI best in open stands in all periods, and in dense stands during the Pre period (Table 2). Over time, PDSI predicted $\Delta$ less well with a declining $r^{2}$ for all stand densities. Climate correlations with BAI and $\Delta$ tended to be lower in dense than open stands in the Recent period compared to the Pre period, when climate correlations tended to be similar across stand densities (Table 2). During the Post period, most climate variables were non-significantly correlated with response variables across stand types, and the few significant findings were more strongly correlated with open stand variables than dense (Table 2).

There were small differences in soil nitrogen between dense and open stand conditions with marginally significant greater net supply in dense stands $(p=0.10)$ (Figure 3a). The difference was driven by $\mathrm{NO}_{3}^{-}$, which was significantly higher in dense stands $(p=0.01)$. There was no significant difference in $\mathrm{NH}_{4}{ }^{+}$between stands. Dense stands had a slightly higher mean nitrogen net supply (measure of available nitrogen in soils) of 17.1 (2.1 standard error) $\mathrm{N}\left(\mu \mathrm{g} / 10 \mathrm{~cm}^{2} / 9\right.$ weeks) whereas open stands had $13.1(0.9) \mathrm{N}$. This was partitioned into $10.6(1.3) \mathrm{NO}_{3}{ }^{-}$and $6.4(1.1) \mathrm{NH}_{4}{ }^{+}$, in dense stands, and $6.1(0.8) \mathrm{NO}_{3}{ }^{-}$and $6.9(0.7) \mathrm{NH}_{4}{ }^{+}$in open stands.

Trees in dense stands had marginally lower leaf nitrogen (Figure $3 \mathrm{~b}$ ). Leaf nitrogen (mean $\% \pm$ standard error) was significantly lower in dense $(0.92 \% \pm 0.05)$ versus open $(1.07 \% \pm 0.03)$ stands in understory trees $(p=0.01)$ (Figure $3 b)$. Percent leaf nitrogen was not statistically different in overstory trees in dense $(1.04 \% \pm 0.02)$ compared to open $(1.09 \% \pm 0.03)$ stands (Figure $3 \mathrm{~b}$ ), consistent with the finding of similar discrimination rates among stands in the Recent period (Figure 2b). Within stands, leaf nitrogen was significantly lower in understory than overstory trees in dense stands $(p=0.04)$, but not in open stands.

Leaf carbon was significantly different between overstory and understory trees within both dense $(0.74 \%, p=$ $0.04)$ and open $(0.70 \%, p=0.03)$ stands. No difference was found between stand densities for overstory or understory trees. Leaf $\mathrm{C}: \mathrm{N}$ ratio was significantly different between overstory and understory trees in dense stands $(5.67, p=0.04)$, and in understory trees between stand densities $(7.77, p=0.01)$. No difference in $\mathrm{C}: \mathrm{N}$ was found between overstory and understory trees in open stands $(0.11, p=0.90)$, or in overstory trees between stand densities $(2.21, p=0.45)$.

\section{Stand Density, Soils, and Fire}

Over the $20^{\text {th }}$ Century, stand density increased in some areas of MCRNA, most notably on El Cajete Pumice (QEC) soils where the highest densities were found (Figure 1). Tree density (mean \pm s.e. stems ha ${ }^{-1}$ ) was significantly higher on QEC soils $(5600 \pm 1537)$ compared to other soil types across MCRNA $(1767 \pm 280)(p=$ 0.05 ). Tree density (mean \pm s.e. stems ha ${ }^{-1}$ ) across mesas was significantly different between San Juan Mesa (4142 $\pm 1030)$ and Cat Mesa $(1638 \pm 340)(p=0.04)$.

Prior to the early 1900s, fire is thought to have limited density across the entire study area (Falk 2004; Swetnam et al. 2016). The mean fire interval (MFI) was significantly different between Cat (16 years) and San Juan (11 years) Mesas $(p=0.03)$. However, we found no significant difference in MFI between dense (11 years) and open stands (16 years), or between QEC (12 years) and other soil types (14 years).

Years since fire (YSF) was relatively consistent and low across the study area in the $19^{\text {th }}$ Century (mean YSF $1800-1849=17$ years, $1850-1899=10$ years). It then increased dramatically over the $20^{\text {th }}$ Century (mean YSF $1900-1949=27$ years, mean YSF 1950-1981 $=54$ years). YSF was significantly different between 1950-1981 and 1800-1942 $(p<0.001)$. Across mesas, the only significant difference $(p<0.05)$ in time since fire from 1801-1981 was in $1892(p=0.03)$ and $1893(p=0.03)$, when much of San Juan Mesa experienced fire but Cat Mesa did not. YSF across dense and open stands, for events from 1801-1981, differed significantly in only two years, 1897 ( $p=$ $0.03)$ and $1899(p=0.04)$.

\section{DISCUSSION}

\section{Mechanisms of Reduced Growth: Water and Nitrogen}


Annual tree radial growth can be regulated by any of several time-varying limiting factors (Fritts 1976). In dry forests of the interior U.S. Southwest, water availability is generally expected to serve as the principal limiting factor. However, in this study of very dense forests we found that a combination of nitrogen limitation plus variable water stress produced the result of high ${ }^{13} \mathrm{C}$ discrimination with low radial growth in overstory ponderosa pine in dense stands.

Changes over time in correlation between climate and the response variables, discrimination and BAI, show a trend towards weaker connection between tree growth and climate, especially in very dense stands. The disconnection is particularly notable in the Post period, when few climate variables are correlated significantly with growth across stand densities or variables. In the Recent period, covering a transition to drought conditions, all climate variables are correlated significantly with growth and discrimination, but generally to a lesser degree than before fire exclusion implying other important factors are affecting the trees. Beyond water availability and climate trends, nitrogen resources are likely to limit and impact tree growth and physiological functioning, as we found in exceptionally dense stands (Rennenberg et al. 2009). This is notable as generally drought is the primary factor of interest affecting ponderosa pine forests, and different management choices might be appropriate if nitrogen is as important or moreso at some places and times (Hurteau et al. 2014; Allen et al. 2015).

These observations suggest that decadal-scale shifts between nitrogen and water limitation can affect carbon assimilation in dense stands following fire exclusion. The lack of nitrogen data from earlier decades adds unavoidable uncertainty to this conclusion, but the trends in tree-ring growth and discrimination, combined with known stand structure changes, strongly imply a nitrogen limitation effect on photosynthesis. In the Recent period, significantly lower radial growth in dense stands, while discrimination remains high, demonstrates ongoing physiological impact of stand density.

Reduced or less available leaf nitrogen in dense stands leads to lower concentrations of the nitrogen-intensive Rubisco enzyme, a decrease in gross photosynthesis, and thus reduced growth. Higher soil nitrogen and reduced leaf nitrogen in dense stands could be a consequence of less available nitrogen in dense stands, with more going to microbial activity than in open stands. Differences in carbon isotopic response might then originate more from soil microbiota and geology than from density (Rennenberg et al. 2009). Trees could adapt to less available nitrogen through reorganization of hydraulic architecture, decreasing leaf area in nutrient-limited trees (McDowell et al. 2008). In this case density would drive the relative decrease in growth, while indirectly contributing to the discrimination response through impacts to resource allocation.

Extreme density-driven impacts to tree growth and physiological functioning will be exacerbated under climate change, with an increasing trend towards hot and dry drought conditions that put forests at increased risk of widespread mortality (Allen et al. 2015). A trend of increasing nitrogen limitation, resulting from increased stand density in the absence of fire, could be an additional stressor increasing tree mortality. Recent, large-scale forest mortality events show the impacts that drought and climate change have on forests (Allen et al. 2010, 2015). Underlying nutrient limitation issues could reduce trees' resilience and contribute to the severity of these events. Over time, a tradeoff of limitations on growth may be occurring, driven by interactions between stand conditions, climate and disturbance.

\section{Stand Density, Soils, and Fire}

Tree growth findings generally aligned with expectations. Overstory trees in dense stands had slower stem growth, with dense stands accumulating $509.8 \mathrm{~cm}^{2}$ less basal area per tree over 1875-2007. Mortality was not different across stand densities, but was highly variable across sites with highest mortality in the densest stand. This likely resulted from greater intraspecific competition for resources, compounded by environmental stress. Interactions between climate-driven variation in water stress and density-related chronic nitrogen limitation led to the forest present on the landscape today.

At MCRNA, the underlying patterns of stand density are explained primarily by substrate differences, when there is no significant variation in fire history. El Cajete Pumice is linked to high tree density, and historically, to Puebloan farming locations with highly productive soils (Gauthier et al. 2007; Swetnam et al. 2016). The superior water-retention and mulching abilities of QEC soils led to high seedling recruitment, and in the absence of fire, to extreme tree density.

\section{CONCLUSIONS}

Fire exclusion beginning in the early $20^{\text {th }}$ Century removed an important constraint on ponderosa pine seedling and sapling survival. In the absence of landscape fire, mass tree establishment (driven by pluvial periods and soil 
characteristics) resulted in extremely high tree density compared to other reference ponderosa pine forests (Abella $e t$ al. 2014; Meunier et al. 2014). Environmental stress and density-driven growth effects compound mortality risk from fire (Van Mantgem et al. 2018).

Increasing tree density over time combined with climate perturbations and underlying soil variation resulted in differential stress impacts on trees in dense stands. Nitrogen likely limited photosynthetic uptake after stand density increased, resulting in overstory trees in dense stands with unexpectedly high ${ }^{13} \mathrm{C}$ discrimination yet low growth relative to trees in open stands, and continued low growth with high discrimination during recent drought. Ongoing and climate-change exacerbated drought is likely to cause increased stress to forests, further impacting growth, physiological functioning, and increasing mortality in dense stands.

Chronic nitrogen limitation in dense ponderosa pine forests is a stressor that could lead to reduced resiliency

under current and projected future drought. Multiple lines of inquiry may be required for accurate analysis of ecosystem conditions in dense modern forests, as demonstrated by the discrimination-nitrogen interaction. We can draw a direct line between fire exclusion, increasing stand density, reduced BAI, and the emergence of joint control on tree growth by available nitrogen and water. Trees can be highly adaptive to environmental stresses and constraints, although observed physiological responses may vary in unexpected ways where forests are pushed beyond their historical variation in density, fire regime, or climate.

\section{ACKNOWLEDGMENTS}

For support and help with fieldwork and in the lab, thanks to Alex Arizpe, Tyson Swetnam, Faith Campbell, Ellis Margolis, and Samantha Stutz. Thanks to Craig Allen, Ellis Margolis, and Tom Swetnam who contributed thoughts and ideas to the project. This work was supported by the US Forest Service, Collaborative Forest Restoration Program (CFRP) and Rocky Mountain Research Station [02-DG-11031000-001, 00-JV-11221615], the Joint Fire Science Program [99-1-3-08], the New Mexico Forest and Woodlands Restoration Institute, and the US Department of Energy Global Change Education Program. NGM was supported by the Department of EnergyOffice of Biological and Environmental Research.

\section{REFERENCES CITED}

Abella, S. R., J. E. Crouse, W. W. Covington, and J. D. Springer, 2014. Diverse responses across soil parent materials during ecological restoration. Restoration Ecology 23:113-121.

Allen, C. D., D. D. Breshears, and N. G. McDowell, 2015. On underestimation of global vulnerability to tree mortality and forest die-off from hotter drought in the Anthropocene. Ecosphere 6:1-55.

Allen, C. D., A. K. Macalady, H. Chenchouni, D. Bachelet, N. McDowell, M. Vennetier, T. Kitzberger, A. Rigling, D. D. Breshears, E. T. Hogg, P. Gonzalez, R. Fensham, Z. Zhang, J. Castro, N. Demidova, J. H. Lim, G. Allard, S. W. Running, A. Semerci, and N. Cobb, 2010. A global overview of drought and heat-induced tree mortality reveals emerging climate change risks for forests. Forest Ecology and Management 259:660-684.

Allen C. D., M. Savage, D. A. Falk, K. F. Suckling, T. W. Swetnam, T. Schulke, P. B. Stacey, P. Morgan, M. Hoffman, and J. T. Klingel, 2002. Ecological restoration of southwestern ponderosa pine ecosystems: A broad framework. Ecological Applications 12:1418-1433.

Allen, C. D., 1998. A ponderosa pine natural area reveals its secrets. In Status and Trends of the Nation's Biological Resources, edited by Mac, M. J., P. A. Opler, C. E. Puckett Haecker, and P. D. Doran, pp. 551-552. U.S. Department of the Interior, U.S. Geological Survey, Reston, VA, USA.

Arnold, J. B., 2018. ggthemes: Extra Themes, Scales and Geoms for 'ggplot2'. R package version 3.4.2. https://CRAN.R-project.org/package=ggthemes

Biondi, F., and F. Qeadan, 2008. A theory-driven approach to tree-ring standardization: defining the biological trend from expected basal area increment. Tree-Ring Research 64:81-96.

Bond, B. J., B. T. Farnsworth, R. A. Coulombe, and W. E. Winner, 1999. Foliage physiology and biochemistry in response to light gradients in conifers with varying shade tolerance. Oecologia 120:183-192.

Brewer, P. W., M. E. Vel'asquez, E. K. Sutherland, and D. A. Falk, 2016. Fire History Analysis and Exploration System (FHAES) version 2.0.2 [computer software]. http://www.fhaes.org

Brown, P. M., and R. Wu, 2005. Climate and disturbance forcing of episodic tree recruitment in a southwestern ponderosa pine landscape. Ecology 86:3030-3038.

Burkhart, H. E., and M. Tomé, 2012. Modeling Forest Trees and Stands. Springer Netherlands, Dordrecht. 
Cook, E. R., C. A. Woodhouse, C. M. Eakin, D. M. Meko, and D. W. Stahle, 2008. North American Summer PDSI Reconstructions, Version 2a. Archived at IGBP PAGES/World Data Center for Paleoclimatology, Data Contribution Series \# 2008-046. http://www.ncdc.noaa.gov/paleo/pdsi.html

Das, A., J. Battles, N. L. Stephenson, and P. J. van Mantgem, 2011. The contribution of competition to tree mortality in old-growth coniferous forests. Forest Ecology and Management 261:1203-1213.

De Boeck, H. J., I, Nijs, C. M. Lemmens, and R. Ceulemans, 2006. Underlying effects of spatial aggregation (clumping) in relationships between plant diversity and resource uptake. Oikos 113:269-278.

Evans, J. R., 1989. Photosynthesis and nitrogen relationships in leaves of $\mathrm{C}_{3}$ plants. Oecologia 78:9-19.

Falk, D. A., 2004. Scaling rules for fire regimes. PhD Dissertation. University of Arizona, Tucson, AZ, USA.

Falk, D., C. Miller, D. McKenzie, and A. Black, 2007. Cross-scale analysis of fire regimes. Ecosystems 10:809-823.

Fritts, H. C. 1976. Tree Rings and Climate. Academic Press, Elsevier. London, UK.

Fulé, P. Z., W. W. Covington, and M. M. Moore, 1997. Determining reference conditions for ecosystem management of southwestern ponderosa pine forests. Ecological Applications 7:895-908.

Gauthier, R., R. Powers, C. Herhahn, M. Bremer, and F. Goff, 2007. Dry farming El Cajete Pumice: Pueblo farming strategies in the Jemez Mountains, New Mexico. In Geology of the Jemez Mountain Region II, pp. 469-474. New Mexico Geological Society, 58th Field Conference Guidebook, Socorro, NM.

Goff, F., J. N. Gardner, S. L. Reneau, and C. J. Goff, 2005. Preliminary Geologic Map of the Redondo Peak Quadrangle, Sandoval County, New Mexico. NM Bureau Geology \& Mineral Resources, Open-file Geologic Map OF-GM-111, scale 1:24,000. Available at http://geoinfo.nmt.edu/index.html

Hurteau, M. D., J. B. Bradford, P. Z. Fulé, A. H. Taylor, and K. L. Martin, 2014. Climate change, fire management, and ecological services in the southwestern US. Forest Ecology and Management 327:280-289.

Keeling, C. D., S. C. Piper, A. F. Bollenbacher, and S. J. Waker, 2005. Monthly Atmospheric ${ }^{13} \mathrm{C}^{12} \mathrm{C}$ Isotopic Ratios for 10 SIO Stations. Archived at Trends: a compendium of data on global change. http://cdiac.ornl.gov/trends/trends.htm

Keeling, E. G., A. Sala, and T. H. DeLuca, 2006. Effects of fire exclusion on forest structure and composition in unlogged ponderosa pine/Douglas-fir forests. Forest Ecology and Management 237:418-428.

Kelley, S., K. A. Kempter, F. Goff, M. Rampey, G. R. Osburn, and C. A. Ferguson, 2003. Geology of the Jemez Springs 7.5-Minute Quadrangle, Sandoval County, New Mexico. NM Bureau Geology \& Mineral Resources, Socorro, NM. Available at http://geoinfo.nmt.edu/index.html

Kolb, T. E., J. K. Agee, P. Z. Fulé, N. G. McDowell, K. Pearson, A. Sala, and R. H. Waring, 2007. Perpetuating old ponderosa pine. Forest Ecology and Management 249:141-157.

Leavitt, S. W., 2010. Tree-ring C-H-O isotope variability and sampling. Science of the Total Environment 408:5244-5253.

Lorimer, C. G., 1983. Tests of age-independent competition indices for individual trees in natural hardwood stands. Forest Ecology and Management 6:343-360.

Lupi, C., H. Morin, A. Deslauriers, S. Rossi, and D. Houle, 2013. Role of soil nitrogen for the conifers of the boreal forest: a critical review. International Journal of Plant and Soil Science 2:155-189.

McCarroll, D., and N. J. Loader, 2004. Stable isotopes in tree rings. Quaternary Science Reviews 23:771-801.

McDowell, N., J. R. Brooks, S. A. Fitzgerald, and B. J. Bond, 2003. Carbon isotope discrimination and growth response of old Pinus ponderosa trees to stand density reductions. Plant, Cell \& Environment 26:631-644.

McDowell, N., W. T. Pockman, C. D. Allen, D. D. Breshears, N. Cobb, T. Kolb, J. Plaut, J. Sperry, A. West, D. G. Williams, and E. A. Yepez, 2008. Mechanisms of plant survival and mortality during drought: Why do some plants survive while others succumb to drought? New Phytologist 178:719-739.

McDowell, N. G., 2011. Mechanisms linking drought, hydraulics, carbon metabolism, and vegetation mortality. Plant Physiology 155:1051-1059.

Meunier, J., P. M. Brown, and W. H. Romme, 2014. Tree recruitment in relation to climate and fire in northern Mexico. Ecology 95:197-209.

Moore, M. M., D. W. Huffman, P. Z. Fulé, W. W. Covington, and J. E. Crouse, 2004. Comparison of historical and contemporary forest structure and composition on permanent plots in southwestern ponderosa pine forests. Forest Science 50:162-176.

New Mexico Geospatial Data Acquisition Coordination Committee (GDACC), State of New Mexico, 2005. Jemez Springs 7.5 Minute Quad 35106, 10M Enhanced DEM, DEM GeoTIFF. Albuquerque, NM: GDACC, EDAC, 2010-10-13. Available at http://rgis.unm.edu/ 
New Mexico Geospatial Data Acquisition Coordination Committee (GDACC), State of New Mexico, 2009.

Redondo Peak 7.5 Minute Quad 35106, 10M Enhanced DEM Hillshade, 2005. Albuquerque, NM: GDACC, EDAC, 2009-07-24. Available at http://rgis.unm.edu/

PRISM Climate Group, 2018. Prism Climate Data. Oregon State University, http://prism.oregonstate.edu, created 11 June 2018.

Rennenberg, H., M. Dannenmann, A. Gessler, J. Kreuzwieser, J. Simon, and H. Papen, 2009. Nitrogen balance in forest soils: Nutritional limitation of plants under climate change stresses. Plant Biology 11:4-23.

QGIS Development Team, 2016. QGIS Geographic Information System. Open Source Geospatial Foundation Project. http://qgis.osgeo.org

R Core Team, 2016. R: A Language and Environment for Statistical Computing. R Foundation for Statistical Computing, Vienna, Austria. https://www.R-project.org/

Sala, A., G. D. Peters, L. R. McIntyre, and M. G. Harrington, 2005. Physiological responses of ponderosa pine in western Montana to thinning, prescribed fire and burning season. Tree Physiology 25:339-348.

Speer, J. H., 2010. Fundamentals of Tree-Ring Research. University of Arizona Press, Tucson.

St. George, S., D. M. Meko, and E. R. Cook, 2010. The seasonality of precipitation signals embedded within the North American Drought Atlas. The Holocene 20:983-988.

Swetnam T. W., J. Farella, C. I. Roos, M. J. Liebmann, D. A. Falk, and C. D. Allen, 2016. Multi-scale perspectives of fire, climate and humans in Western North America and the Jemez Mountains, U.S.A. Philosophical Transactions of the Royal Society B 371:20150168. http://dx.doi.org/10.1098/rstb.2015.0168

USGS National Gap Analysis Program (GAP), 2009. Protected Area Database of the United States (PAD-US_v1). Edition 1.0. Moscow: ID, 2009-04-06. Available at http://gapanalysis.usgs.gov/PADUS/

Van Mantgem P., D. A. Falk, E. C. Williams, A. Das, and N. Stephenson. 2018. Pre-fire drought and competition mediate post-fire conifer mortality in western US National Parks. Ecological Applications 28:1730-1739 doi: 10.1002/eap.1778.

Wickham, H., 2017. tidyverse: Easily Install and Load the 'Tidyverse'. R package version 1.2.1. https://CRAN.Rproject.org/package=tidyverse. 
Table 1. Variable means and SD. Climate (left) and response variable (right) means with standard deviation in parentheses, by time period and stand density class. Growing season (GS, March-September) mean temperature $\left({ }^{\circ} \mathrm{C}\right)$, maximum VPD (hPa), PDSI, and water year (WY, previous October-current September) precipitation $(\mathrm{mm})$ are the climate variables presented. Temperature, VPD, and precipitation variables are derived from PRISM climate reconstruction at 4-km resolution around the study area. Asterisks indicate significant difference between stand density classes within the given time period.

\begin{tabular}{|c|c|c|c|c|c|c|}
\hline \multirow{2}{*}{ Period } & \multicolumn{2}{|c|}{ Climate } & \multirow{2}{*}{ Period } & \multicolumn{2}{|c|}{ Response } & \\
\hline & Variable & Mean (SD) & & Stand - Variable & Mean (SD) & \\
\hline \multirow[t]{4}{*}{ Pre } & PDSI (GS) & $-0.32(2.83)$ & \multirow[t]{4}{*}{ Pre } & Open - BAI & $7.16(3.89)$ & \\
\hline & PPT (WY) & $43.8(9.3)$ & & Dense - BAI & $6.50(4.25)$ & \\
\hline & Tmean (GS) & $13.1(0.8)$ & & Open - $\Delta$ & $14.45(0.71)$ & \\
\hline & VPDmax (GS) & $18.8(1.5)$ & & Dense - $\Delta$ & $14.75(0.67)$ & \\
\hline \multirow[t]{4}{*}{ Post } & PDSI (GS) & $-0.36(2.37)$ & \multirow[t]{4}{*}{ Post } & Open - BAI & $6.69(2.33)$ & \multirow{2}{*}{ * } \\
\hline & PPT (WY) & $42.5(9.4)$ & & Dense - BAI & $3.45(1.70)$ & \\
\hline & Tmean (GS) & $13.0(0.8)$ & & Open - $\Delta$ & $14.84(0.28)$ & \\
\hline & VPDmax (GS) & $19.2(1.5)$ & & Dense - $\Delta$ & $15.59(0.17)$ & \\
\hline \multirow[t]{4}{*}{ Recent } & PDSI (GS) & $-0.47(1.81)$ & \multirow[t]{4}{*}{ Recent } & Open - BAI & $8.14(4.44)$ & \multirow{2}{*}{ * } \\
\hline & PPT (WY) & $45.6(12.1)$ & & Dense - BAI & $3.42(1.69)$ & \\
\hline & Tmean (GS) & $13.5(0.8)$ & & Open - $\Delta$ & $16.50(0.60)$ & \\
\hline & VPDmax (GS) & $19.5(2.2)$ & & Dense - $\Delta$ & $16.24(0.50)$ & \\
\hline
\end{tabular}


Table 2. Climate correlations. Pearson's $r$ correlations between reconstructed climate variables and annual tree response variables across stand densities. Climate variables are growing season (GS, March-September) mean temperature $\left({ }^{\circ} \mathrm{C}\right)$, maximum VPD (hPa), PDSI, and water year (WY, previous October-current September) precipitation $(\mathrm{mm})$. Response variables are basal area increment $\left(\mathrm{BAI}, \mathrm{cm}^{2}\right)$ and carbon isotope discrimination $\left(\Delta,{ }^{13} \mathrm{C} /{ }^{12} \mathrm{C} \%\right.$ ). NS indicates non-significant relationships.

\begin{tabular}{|c|c|c|c|c|c|}
\hline Period & Stand - Variable & PDSI (GS) & PPT (WY) & Tmean (GS) & VPDmax (GS) \\
\hline \multirow{3}{*}{ Pre } & Open - BAI & 0.78 & 0.80 & -0.75 & -0.89 \\
\cline { 2 - 6 } & Dense - BAI & 0.92 & 0.71 & -0.77 & -0.84 \\
\cline { 2 - 6 } & Open - $\Delta$ & 0.95 & 0.71 & -0.65 & -0.69 \\
\cline { 2 - 6 } & Dense - $\Delta$ & 0.93 & 0.71 & -0.72 & -0.68 \\
\hline \hline \multirow{7}{*}{ Post } & Open - BAI & 0.75 & NS & NS & NS \\
\cline { 2 - 6 } & Dense - BAI & 0.63 & NS & NS & NS \\
\cline { 2 - 6 } & Open - $\Delta$ & NS & NS & -0.82 & NS \\
\cline { 2 - 6 } & Dense - $\Delta$ & NS & 0.63 & NS & NS \\
\hline \multirow{3}{*}{ Recent } & Open - BAI & 0.55 & 0.87 & -0.76 & -0.73 \\
\cline { 2 - 6 } & Dense - BAI & 0.46 & 0.78 & -0.68 & -0.69 \\
\cline { 2 - 6 } & Open - $\Delta$ & 0.49 & 0.63 & -0.69 & -0.79 \\
\cline { 2 - 6 } & Dense - $\Delta$ & 0.49 & 0.44 & -0.44 & -0.56 \\
\hline \hline
\end{tabular}




\section{Figure Captions}

Figure 1. Sampling sites, soil geologic origin and tree density. Monument Canyon Research Natural Area (MCRNA) (at right), located in the Santa Fe National Forest in northern New Mexico (at left, national forest lands shaded in gray), with 50-m elevation contours derived from DEM (NM GDACC 2009; USGS GAP 2009). Black circles indicate isotope-sampled target trees in dense stands, white circles indicate target trees in open stands, and grayscale diamonds are gridded sampling points used for fire history and density analysis, with darker colors indicating denser stands (range 186-15839 trees $\mathrm{ha}^{-1}$ ). The thick dashed line indicates median stem density $\left(2300 \mathrm{stems} \mathrm{ha}^{-1}\right)$, used as a cutoff for open/dense sites. Dotted lines are one and two standard deviations above the mean (6093 and 9327 stems ha $^{-1}$, respectively), derived from an inverse distance weighted interpolation of sampled point stem density. Maximum density is found at the lower right of the study area. Shaded dark gray areas indicate El Cajete pumice (QEC), where the densest stands occur (Goff et al. 2005; Kelley et al. 2003).

Figure 2. Time series of discrimination and growth. Solid black points and line indicates dense stands; white points and dotted lines indicates open stands throughout. Gray boxes indicate isotope sampling periods. White dot-dash line at 1900 indicates cessation of frequent fire, and gray dot-dash line at 1919 indicates the pluvial event linked to dense stand seedling establishment. (a) Carbon isotope discrimination $(\Delta \%)$ in dense (black circles) and open (white circles) stands in Pre (1887-1907) where $\Delta$ is similar across stands, Post (1971-1980) where $\Delta$ is unexpectedly lower in open stands, and Recent (1990-2007) periods where $\Delta$ is variable and responsive to drought onset. All but one core was missing the 2002 ring. (b) Boxplots of carbon isotope discrimination $(\Delta \%)$ across the three periods, with dense in gray and open in white. (c) Mean basal area increment $(\mathrm{BAI} \mathrm{cm})$ time series for trees in dense and open conditions. (d) Mean cumulative basal area $\left(\mathrm{cm}^{2}\right)$ for dense and open trees, as categorized by density surrounding individual trees.

Figure 3. Soil and leaf nitrogen. Available nutrient surplus over the 9 -week sampling period $\left(\mu \mathrm{g} / 10 \mathrm{~cm}^{2}\right)$ (a) and mean \% leaf nitrogen (b) in overstory and understory tree leaves, in open and dense stands. Asterisks indicate significant difference $(p<0.05)$ between open and dense stands. Marginally more total $\mathrm{N}$ was present in dense soils (black square, $p=0.10$ ), driven by a significant difference in $\mathrm{NO}_{3}^{-}(p=0.01)$. Percent leaf nitrogen was significantly different between overstory and understory trees in dense $(p=0.01)$, but not in open stands. 
Figures

Figure 1.

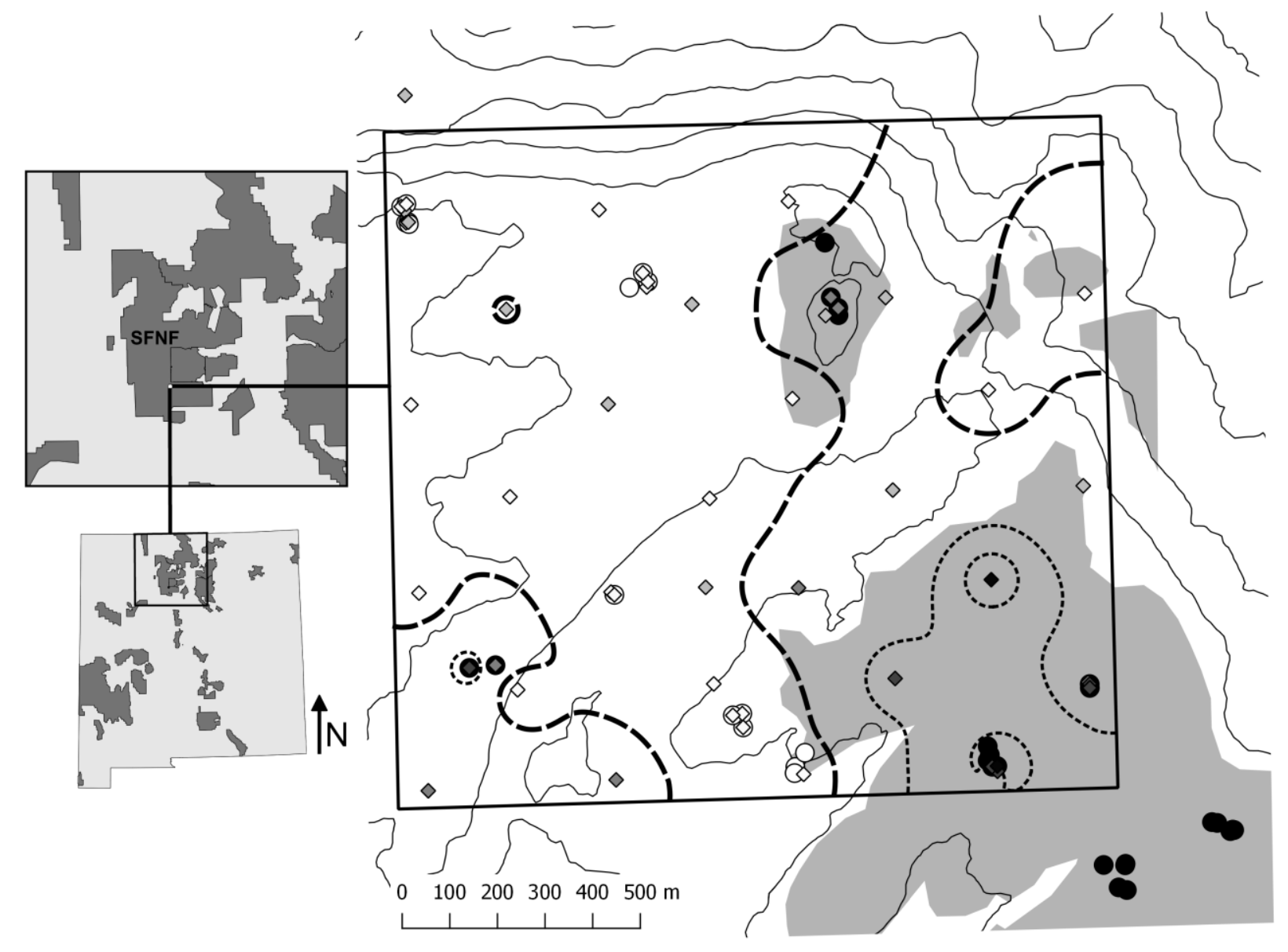


Figure 2.
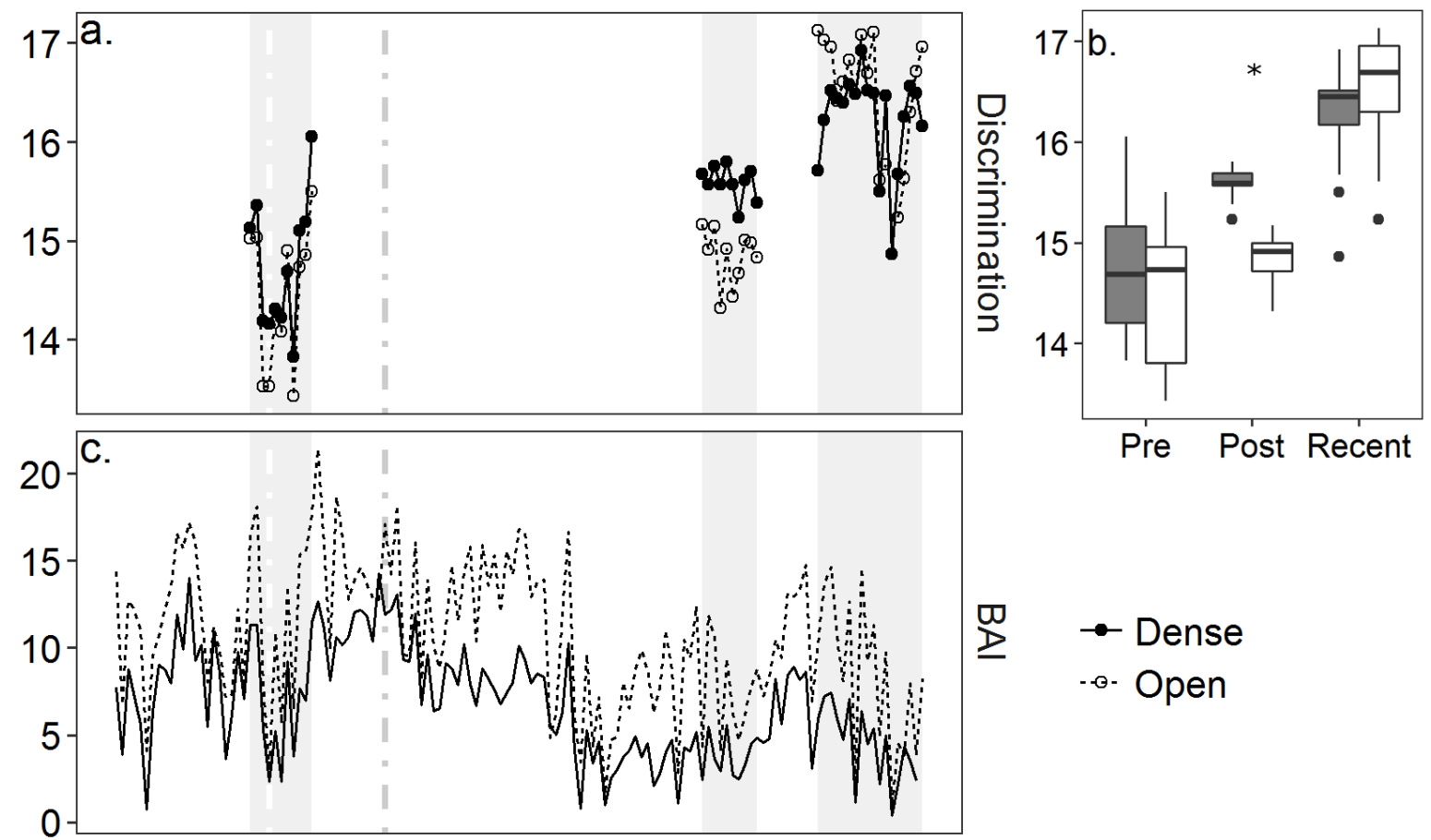

$$
\begin{array}{ll}
\varpi & \rightarrow \text { Dense } \\
\unrhd \quad & -\bullet-\text { Open }
\end{array}
$$

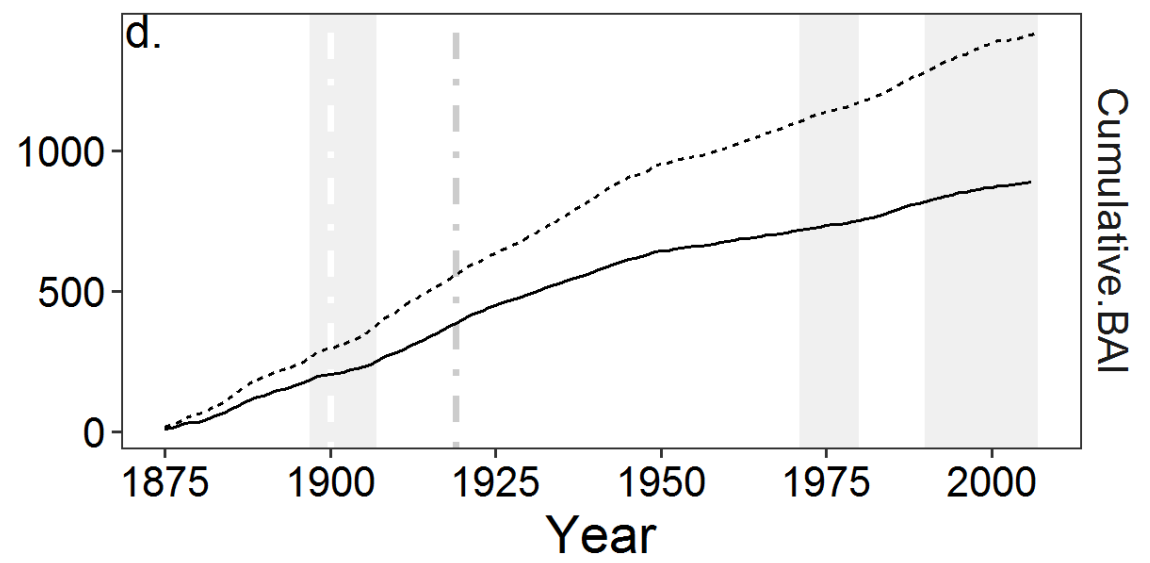


Figure 3.

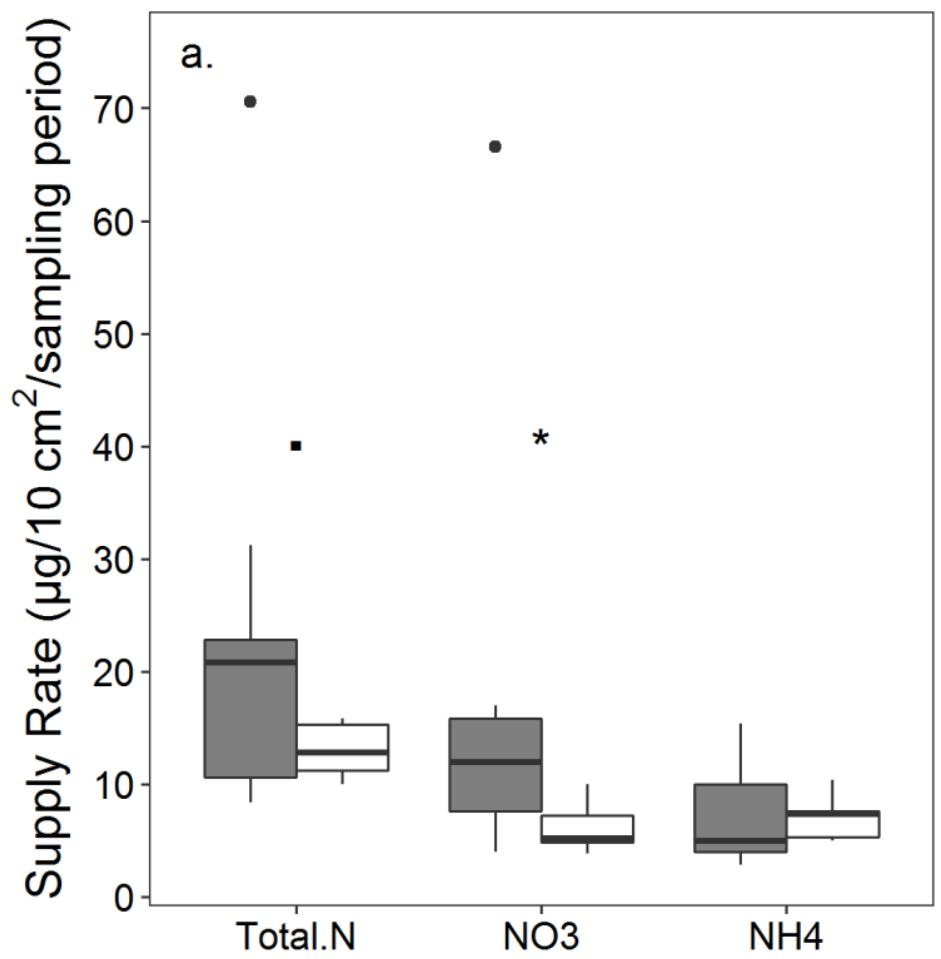

甶Dense

官Open

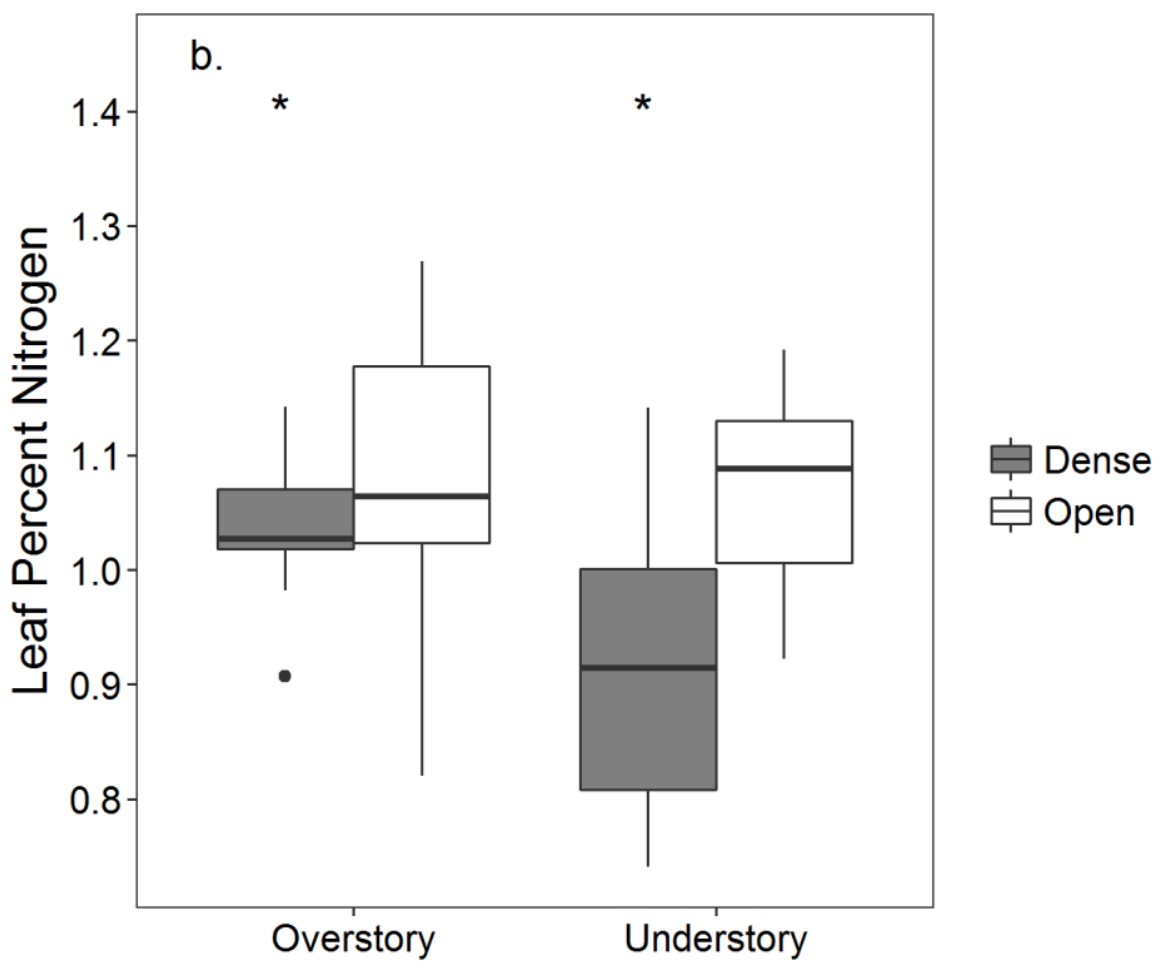

